\title{
PENGUKURAN TINGKAT KUALITAS PELAYANAN PIT-STOP KOPI GRESIK
}

\author{
Narto \\ Program Studi Teknik Industri, Fakultas Teknik, Universitas Qomaruddin Gresik \\ Email:nartonazriel@gmail.com
}

\begin{abstract}
Abstrak -- Pit-Stop Kopi merupakan salah satu coffee shop yang ada di kota Gresik, dengan segmentasi konsumennya adalah pasar menengah dan bawah dengan harga yang sangat terjangkau oleh setiap kalangan masyarakat. Berdasarkan survey awal diperoleh beberapa keluhan yang dirasakan oleh pelanggan, diantaranya yaitu tempat duduk hanya untuk satu orang sehingga jika datang bersama dengan jumlah yang banyak harus menyesuaikan terlebih dahulu tempatnya, pelayanan yang kurang representatif, varian rasa terbatas pada setiap menu yang ditawarkan. Penelitian ini bertujuan untuk mengukur kepuasan pelanggan dengan menggunakan metode Servqual, IPA dan PGCV dengan jumlah responden 100 orang. Hasil penelitian menunjukan bahwa terdapat 3 atribut pada kuadran A yaitu P4 fasilitas pendukung sangat lengkap dengan nilai PGCV sebesar 5,99, P5 area parkir luas dan aman dengan nilai PGCV sebesar 5,54, P10 segera memberikan pelayanan yang tepat sesuai dengan keinginan pelanggan dengan nilai PGCV sebesar 5,50.Tindakan perbaikan yang dilakukan untuk meningkatkan kualitas pelayanan yaitu melakukan pembersihan secara rutin terhadap fasilitas penunjang yang dimiliki oleh Pit-Stop Gresik, Penataan parkir yang baik oleh petugas parkir harus selalu diperhatikan sehingga efektivitas penggunaan lahan parkir bisa maksimal, pelayan harus memperhatikan ketepatan dan kecepatan dalam melayani pelanggan sehingga akan tercipta rasa puas oleh pelanggan.
\end{abstract}

Kata kunci: IPA, Kualitas, PGVC, Servqual, IPA

\begin{abstract}
Coffee Pit Stop is one of the coffee shops in the city of Gresik, with its segmentation of consumers being middle and lower markets at prices that are very affordable for every community. Based on the initial survey, some complaints were felt by the customer, including seating for only one person so that if they came together with a large number they had to adjust their place first, the service was less representative; the taste variants were limit to each menu offered. This study aims to measure customer satisfaction by using the Servqual, IPA, and PGCV method with 100 respondents. The results showed that there were three attributes in quadrant $A$ namely $P 4$ very complete support facilities with PGCV values of 5.99, P5 wide and safe parking area with a PGCV value of 5.54, P10 immediately providing the right service according to customer desires with amount PGCV is 5.50. The corrective action taken to improve service quality is to carry out routine cleaning of the supporting facilities owned by Gresik Pit Stop. Suitable parking arrangements by parking officers must always consider so that the effectiveness of land use can be maximized, and the waiter must pay attention to the accuracy and speed in serving customers so that customer satisfaction will be creating.
\end{abstract}

Keywords: IPA, PGCV, Quality, Servqual

\section{PENDAHULUAN}

Berkembangnya bisnis coffee shop dewasa ini menjadi salah satu tempat pilihan yang sangat cocok dalam melakukan kegiatan diskusi atau kegiatan lainnya. Kopi saat ini dijual bukan hanya sebagai sebuah produk, namun juga bagian dari lifestyle seiring dengan banyak berkembangangnya coffee shop yang semakin berkembang (Ranitaswari, Mulyani, \& Sadyasma, 2018).
Kepuasan pelanggan dapat diperoleh dari beberapa cara, salah satunya adalah manajemen mempunyai komitmen kuat untuk memberikan pelayanan yang optimal kepada pelanggan (Nuryani, Santoso, \& Deoranto, 2014). Kepuasan adalah perasaan seseorang dalam menilai suatu produk atau jasa dengan mengukur persepsi tertentu sesuai dengan harapannya (Wicaksono, Setyanto, \& Oktavianty, 2014). Untuk menciptakan kepuasan pelanggan perusahaan 
harus mempertahankan Kualitas produk dan pelayanan (Suyitno \& Sudarso, 2019). Pemberian pelayanan yang diberikan perusahaan dijadikan oleh konsumen sebagai pembanding terhadap penilaian harapan dan kinerja untuk mendapatkan kepuasan pelayanan. Persepsi pelanggan akan menjadi sudut pandang penilaian terhadap kualitas pelayanan yang diberikan oleh penyedia layanan (Devani \& Rizko, 2016). Bila harapan terpenuhi oleh pelayanan perusahaan, maka dapat dikatakan memiliki kualitas yang baik dan akan dapat memuaskan pelanggan (Winarno \& Absror, 2017).

Pit-Stop Kopi merupakan salah satu coffee shop yang ada di kota Gresik, segmentasi konsumennya adalah pasar menengah dan bawah dengan harga yang sangat terjangkau oleh setiap kalangan masyarakat. Kata Pit-Stop diambil dari pengertian bahwa coffee shop ini merupakan tempat pemberhentian sejenak dalam perjalanan jauh untuk beristirahat.

Selama ini pihak manajemen Pit-Stop Kopi belum pernah melakukan pengukuran kualitas pelayanan untuk mengetahui tingkat kepuasan pelanggan, sehingga dalam meningkatkan kualitas pelayanan dan mengatasi keluhan pelanggan belum terlaksana secara maksimal. Dari hasil survey awal terhadap kualitas pelayanan di Pit-Stop Kopi diperoleh beberapa keluhan yang dialami oleh pelanggan, diantaranya yaitu tempat duduk hanya untuk satu orang sehingga jika datang bersama dengan jumlah yang banyak harus menyesuaikan terlebih dahulu tempatnya, pelayanan yang kurang representatif, varian rasa terbatas pada setiap menu yang ditawarkan. Menurut Jalal \& Jayamandau (2016), penilaian pelanggan juga bukan hanya dari cita rasa, akan tetapi dari aspek kinerja manajemen, pengelolaan tempat, pelayanan, lokasi, fasilitas dan lain sebagainya.

Adanya ketidaksesuaian antara tingkat kepuasan pelanggan terhadap kualitas pelayanan yang diberikan oleh pihak Pit-Stop Kopi maka perlu dilakukan pengukuran terhadap kualitas pelayanan. Tujuan penelitian ini adalah untuk mengetahui faktor yang berpengaruh terhadap kepuasan pelanggan dan memberikan rekomendasi perbaikan untuk peningkatan kepuasan pelanggan terhadap kualitas pelayanan di Pit-Stop Kopi Gresik.

\section{METODE PENELITIAN}

Penelitian dilakukan untuk mengukur kualitas pelayanan di Pit-Stop Kopi Kota Gresik. Teknik pengumpulan data menggunakan penyebaran kuesioner dengan penilaian skala likert.
Penyebaran kuesioner dengan teknik purposive sampling diberikan kepada pelanggan dengan jumlah 100 responden.

\section{Servqual}

Salah satu metode yang dapat digunakan untuk mengukur kualitas pelayanan adalah dengan menggunakan metode Servqual. Metode ini dapat mengukur tingkat kepentingan dan harapan terhadap kualitas pelayanan sehingga dapat menganalisis kemungkinan terjadinya permasalahan layanan yang diberikan oleh pihak manajemen. Menurut Nuryani et al. (2014) pengukuran tersebut dilakukan dengan mencari nilai gap masing-masing atribut yang ada dalam 5 dimensi dalam pengukuran suatu kualitas terdiri dari yaitu responsiveness (daya tanggap), reliability (kehandalan), assurance (jaminan), empathy (perhatian), dan tangible (bukti fisik). Menurut (Tjiptono, 2008) Skor Servqual adalah hasil dari skor persepsi dikurangi dengan skor ekspektasi masing-masing atribut.

$$
\text { Skor SERVQUAL }=\underset{\text { Ekspektasi }}{\text { Skor Persepsi }}-\underset{\text { Skor }}{\text { (1) }}
$$

\section{Importance Performance Analysis}

Sedangkan menurut Sukwadi (2014) Importance Performance Analysis (IPA) adalah metode yang digunakan untuk memetakan persepsi pelanggan terhadap tingkat kepentingan dengan persepsi pelanggan untuk mengidentifikasi layanan yang perlu ditingkatkan, lebih lanjut merupakan konsep dengan menggunakan multi-atribut (Winarno \& Absror, 2017).

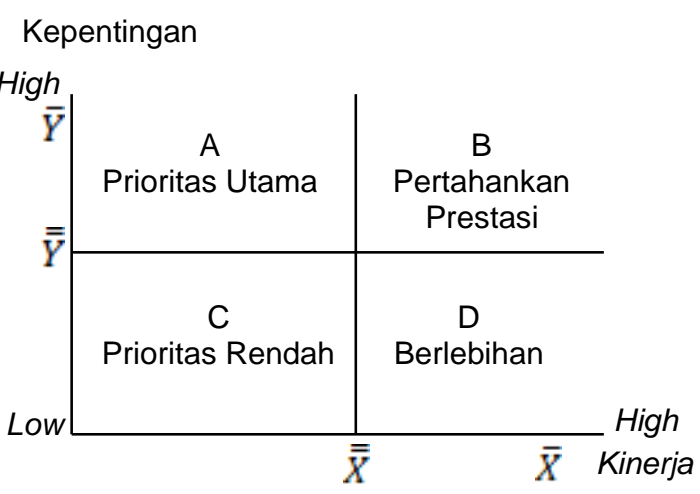

\section{Gambar 1. Matriks Importance Performance Analysis}

Importance Performance Analysis (IPA) dipergunakan untuk mendapatkan atribut-atribut yang mempunyai pengaruh terhadap hasil dari 5 dimensi SERVQUAL (Erni, Sriwana, \& Yolanda, 2014). Untuk memahami kepuasan pelanggan disusun kerangka kerja dalam memperoleh 
kepuasan pelanggan terkait kepentingan (importance) terhadap atribut dan penilaian pelanggan terhadap kinerja organisasi (performance) (Gambar 1) (Supranto, 2006).

Untuk mengetahui tingkat kesesuaian antara kinerja dengan kepentingan dari kualitas pelayanan, maka dapat dihitung dengan rumus:

$T_{k i}=\frac{\overline{X \imath}}{\overline{Y \imath}} x 100 \%$

Keterangan:

$\begin{array}{ll}T k i & =\text { Tingkat kesesuaian responden } \\ \overline{X l} & =\text { Rata-rata penilaian kinerja } \\ Y i & =\text { Rata-rata penilaian kepentingan }\end{array}$

\section{Potential Gain Customer Value}

Selanjutnya dengan pendekatan Potential Gain Customer Value akan diperoleh hasil berkaitan dengan atribut apa yang secara prioritas harus diperbaiki untuk memenuhi kepuasan pelanggan (Sukwadi, 2014; Widyarto, Djamal, \& Adhim, 2018). Sedangkan menurut Darmawan, Mulyadi, \& Busri (2014) PGCV merupakan metode lanjutan dari metode IPA yang dapat digunakan untuk melengkapi analisis IPA dapat membagi atribut ke dalam bagian yang perlu prioritas perbaikan. Indeks PGCV diperoleh dari hasil perhitungan terhadap nilai Achieved Customer Value (ACV) dengan mengalikan antara atribut kepentingan dengan atribut kinerja.

$\mathrm{ACV}=\mathrm{X} \times \mathrm{Y}$

Keterangan:

$\mathrm{ACV}=$ Nilai pencapaian konsumen

$\mathrm{X} \quad=$ Rata-rata kinerja

$\mathrm{Y} \quad=$ Rata-rata kepentingan

Setelah mendapat nilai ACV, maka selanjutnya adalah mencari UDCV atau Ultimately Desired Customer Value, yang mana nilai ini didapatkan dengan rumus:

$\mathrm{UDCV}=\mathrm{Y} \times \mathrm{X}_{\max }$

Keterangan:

UDCV = Nilai akhir keinginan konsumen

$\mathrm{Y} \quad=$ Nilai rata-rata untuk kepentingan

$\mathrm{X}_{\max }=$ Nilai kinerja maksimum dalam skala likert yang dipilih

Dan terakhir nilai indeks PGCV adalah nilai Ultimate Desired Customer Value dikurangi dengan Achieved Customer Value, yaitu:

$\mathrm{PGCV}=\mathrm{UDCV}-\mathrm{ACV}$

Apabila atribut mempunyai nilai indeks PGCV terbesar, maka item tersebut mendapatkan prioritas utama untuk diperbaiki kinerjanya

\section{HASIL DAN PEMBAHASAN \\ Service Quality (Servqual)}

Perhitungan rata-rata kinerja dan kepentingan terhadap masing-masing atribut yang menghasilkan gap, ditunjukan pada tabel 1 .

Tabel 1. Nilai gap antara kinerja dengan kepentingan

\begin{tabular}{|c|c|c|c|}
\hline Pernyataan & $\begin{array}{c}\text { Rata- } \\
\text { Rata } \\
\text { Kinerja } \\
\end{array}$ & $\begin{array}{l}\text { Rata-Rata } \\
\text { Kepentingan }\end{array}$ & Gap \\
\hline \multicolumn{4}{|l|}{ Tangible (Bukti Fisik) } \\
\hline $\begin{array}{l}\text { Kebersihan dan kerapian } \\
\text { ruangan sangat terjaga }\end{array}$ & 3,52 & 3,94 & $-0,42$ \\
\hline $\begin{array}{l}\text { Suasana ruangan yang } \\
\text { tenang dan representatif }\end{array}$ & 3,44 & 3,87 & $-0,43$ \\
\hline $\begin{array}{l}\text { Penerangan ruangan sangat } \\
\text { cukup }\end{array}$ & 3,55 & 3,9 & $-0,35$ \\
\hline $\begin{array}{l}\text { Fasilitas pendukung sangat } \\
\text { lengkap }\end{array}$ & 3,5 & 3,99 & $-0,49$ \\
\hline Area parkir luas dan aman & 3,64 & 4,07 & $-0,43$ \\
\hline \multicolumn{4}{|l|}{ Reliability (Kehandalan) } \\
\hline $\begin{array}{l}\text { Pelayan memberikan } \\
\text { pelayanan dengan cepat }\end{array}$ & 3,49 & 3,94 & $-0,45$ \\
\hline $\begin{array}{l}\text { Pelayan memberikan } \\
\text { informasi yang tepat }\end{array}$ & 3,53 & 3,9 & $-0,37$ \\
\hline $\begin{array}{l}\text { Pelayan menyajikan } \\
\text { pesanan sesuai dengan janji } \\
\text { yang disampaikan }\end{array}$ & 3,63 & 3,93 & $-0,30$ \\
\hline \multicolumn{4}{|l|}{$\begin{array}{l}\text { Responsiveness (Daya } \\
\text { Tanggap) }\end{array}$} \\
\hline $\begin{array}{l}\text { Pemberian informasi yang } \\
\text { cukup jelas kepada } \\
\text { pelanggan }\end{array}$ & 3,82 & 3,93 & $-0,11$ \\
\hline $\begin{array}{l}\text { Segera memberikan } \\
\text { pelayanan yang tepat } \\
\text { sesuai dengan keinginan } \\
\text { pelanggan }\end{array}$ & 3,68 & 4,17 & $-0,49$ \\
\hline $\begin{array}{l}\text { Kecepatan pelayan dalam } \\
\text { merespon keluhan } \\
\text { pelanggan }\end{array}$ & 3,64 & 3,9 & $-0,26$ \\
\hline $\begin{array}{l}\text { Pelayan memberikan } \\
\text { penjelasan tentang produk } \\
\text { yang dijual dengan lengkap }\end{array}$ & 3,81 & 3,99 & $-0,18$ \\
\hline \multicolumn{4}{|l|}{ Assurance (Jaminan) } \\
\hline $\begin{array}{l}\text { Jam Buka Pit-Stop Kopi } \\
\text { tepat waktu }\end{array}$ & 3,74 & 4,07 & $-0,33$ \\
\hline $\begin{array}{l}\text { Pelayanan kepada } \\
\text { pelanggan harus dilakukan } \\
\text { dengan cepat. }\end{array}$ & 3,86 & 3,94 & $-0,08$ \\
\hline $\begin{array}{l}\text { Pelayanan kepada } \\
\text { pelanggan harus dilakukan } \\
\text { dengan tepat. }\end{array}$ & 3,79 & 3,9 & $-0,11$ \\
\hline \multicolumn{4}{|l|}{ Empathy (Perhatian) } \\
\hline $\begin{array}{l}\text { Pelayanan yang baik tanpa } \\
\text { memandang status sosial }\end{array}$ & 3,85 & 3,93 & $-0,08$ \\
\hline $\begin{array}{l}\text { Petugas sabar dalam } \\
\text { melayani pelanggan dan } \\
\text { mendengarkan keinginan } \\
\text { pelanggan }\end{array}$ & 3,76 & 3,93 & $-0,17$ \\
\hline $\begin{array}{l}\text { Petugas bersikap ramah } \\
\text { dan sopan }\end{array}$ & 3,78 & 3,94 & $-0,16$ \\
\hline $\begin{array}{l}\text { Pelayan selalu memberikan } \\
\text { sikap senyum sapa dan } \\
\text { santun }\end{array}$ & 4,04 & 4,18 & $-0,14$ \\
\hline Rata - Rata & 3,69 & 3,97 & $-0,28$ \\
\hline
\end{tabular}

Berdasarkan hasil analisis awal menggunakan metode servqual maka dapat diketahui bahwa:

1. Nilai rata-rata tertinggi untuk tingkat kinerja 
adalah atribut P19 yaitu pelayan selalu memberikan sikap senyum sapa dan salam kepada pelanggan yang datang dengan nilai sebesar 4,04. Sedangkan nilai terendah pada atribut P2 yaitu Suasana ruangan yang tenang dan representatif dengan nilai sebesar 3,44 .

2. Nilai rata-rata tertinggi tingkat kepentingan adalah atribut P19 Pelayan selalu memberikan sikap senyum sapa dan santun dengan nilai sebesar 4,18. Sedangkan nilai terendah pada atribut P3, P7, P11 dan P15 dengan nilai masing-masing sebesar 3,9.

3. Secara keseluruhan nilai rata-rata tingkat kinerja adalah sebesar 3,69 dan nilai rata-rata tingkat kepentingan adalah sebesar 3,97 dengan nilai gap rata-rata sebesar -0,28. Hal ini menunjukan bahwa secara keseluruhan kualitas layanan yang diberikan oleh Pit-Stop Kopi masih dibawah harapan pelanggan.

\section{Importance Performance Analysis (IPA)}

Analisis selanjutnya yaitu mengukur sejauh mana tingkat kesesuaian antara kinerja dan kepentingan dari kualitas pelayanan yang telah diberikan kepada pelanggan berdasarkan Importance Performance Analysis (IPA) dalam bentuk diagram kartesius (Gambar 1).

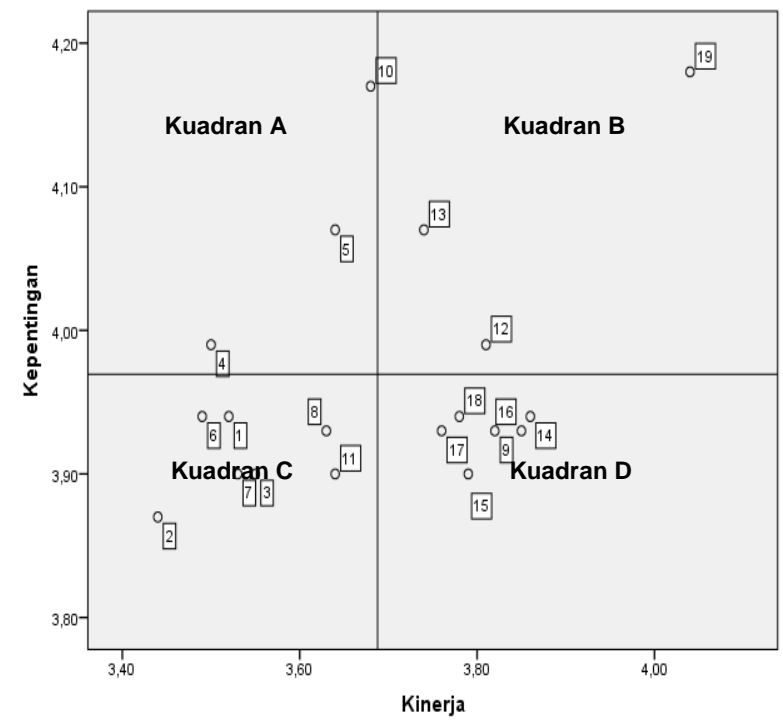

Gambar 1. Diagram kartesius tingkat kinerja dan kepentingan

Dari gambar 1 dapat diperoleh bahwa terdapat 3 atribut yang masuk dalam kuadran $A$ (prioritas utama) yaitu Fasilitas pendukung sangat lengkap, Area parkir luas dan aman, Segera memberikan pelayanan yang tepat sesuai dengan keinginan pelanggan. Hal tersebut berarti pelanggan mengharapkan tingkat kepentingan yang tinggi, namun performa dari pelayanan tersebut kurang maksimal sehingga perlu ada perbaikan yang lebih fokus pada kriteria tersebut. Kuadran ini merupakan prioritas utama dalam melakukan perbaikan guna meningkatkan performansi setiap atribut pelayanannya, agar kepuasan pelanggan dapat ditingkatkan.

Pada kuadran B (pertahankan prestasi) terdapat 3 atribut antara lain Pelayan memberikan penjelasan tentang produk yang dijual dengan lengkap, Jam Buka Pit-Stop Kopi tepat waktu, Pelayan selalu memberikan sikap senyum sapa dan santun.

Di kuadran C (Prioritas rendah) terdapat tujuh atribut antara lain Kebersihan dan kerapian ruangan sangat terjaga, suasana ruangan yang tenang dan representatif, penerangan ruangan sangat cukup, pelayan memberikan pelayanan dengan cepat, pelayan memberikan informasi yang tepat, pelayan menyajikan pesanan sesuai dengan janji yang disampaikan, kecepatan pelayan dalam merespon keluhan pelanggan.

Sedangkan yang masuk di kuadran D (berlebihan) Atribut-atribut tersebut antara lain pemberian informasi yang cukup jelas kepada pelanggan, pelayanan kepada pelanggan harus dilakukan dengan cepat, pelayanan kepada pelanggan harus dilakukan dengan tepat, pelayanan yang baik tanpa memandang status sosial, petugas sabar dalam melayani pelanggan dan mendengarkan keinginan pelanggan, petugas bersikap ramah dan sopan.

\section{Potential Gain Customer Value (PGCV)}

Penentuan urutan prioritas perbaikan pelayanan mengacu pada pengukuran pada indeks Potential Gain Customer Value (PGCV). Indeks PGCV digunakan untuk menentukan atribut-atribut yang berpeluang paling besar untuk dilakukan perbaikan yang dapat memberikan nilai tambah atau keuntungan bagi perusahaan secara signifikan. Langkah awal yaitu menentukan nilai ACV (Achieved Customer Value) dengan perhitungan sebagai berikut:

ACV atribut $1=3,52 \times 3,94=13,87$

ACV atribut $2=3,44 \times 3,87=13,31$

Selanjutnya nilai UDCV (Ultimately Desired Customer Value) diperoleh dari perhitungan sebagai berikut:

UDCV atribut $1=3,94 \times 5=19,7$

UDCV atribut $2=3,87 \times 5=19,35$

Sedangkan untuk nilai PGCV diperoleh dari perhitungan sebagai berikut:

PGCV atribut $1=19,7-13,87=5,83$

PGCV atribut $2=19,35-13,31=6,04$ 
Hasil perhitungan keseluruhan untuk ACV dan UDCV serta PGCV masing-masing atribut ditunjukan pada tabel 2 .

Tabel 2. Indeks PGCV

\begin{tabular}{cccccc}
\hline Atribut & $\begin{array}{c}\text { Rata- } \\
\text { Rata } \\
\text { Tingkat } \\
\text { Kinerja }\end{array}$ & $\begin{array}{c}\text { Rata-Rata } \\
\text { Tingkat } \\
\text { Kepentingan }\end{array}$ & ACV & UDCV & PGCV \\
\hline P1 & 3,52 & 3,94 & 13,87 & 19,70 & 5,83 \\
\hline P2 & 3,44 & 3,87 & 13,31 & 19,35 & 6,04 \\
\hline P3 & 3,55 & 3,9 & 13,85 & 19,50 & 5,66 \\
\hline P4 & 3,5 & 3,99 & 13,97 & 19,95 & 5,99 \\
\hline P5 & 3,64 & 4,07 & 14,81 & 20,35 & 5,54 \\
\hline P6 & 3,49 & 3,94 & 13,75 & 19,70 & 5,95 \\
\hline P7 & 3,53 & 3,9 & 13,77 & 19,50 & 5,73 \\
\hline P8 & 3,63 & 3,93 & 14,27 & 19,65 & 5,38 \\
\hline P9 & 3,82 & 3,93 & 15,01 & 19,65 & 4,64 \\
\hline P10 & 3,68 & 4,17 & 15,35 & 20,85 & 5,50 \\
\hline P11 & 3,64 & 3,9 & 14,20 & 19,50 & 5,30 \\
\hline P12 & 3,81 & 3,99 & 15,20 & 19,95 & 4,75 \\
\hline P13 & 3,74 & 4,07 & 15,22 & 20,35 & 5,13 \\
\hline P14 & 3,86 & 3,94 & 15,21 & 19,70 & 4,49 \\
\hline P15 & 3,79 & 3,9 & 14,78 & 19,50 & 4,72 \\
\hline P16 & 3,85 & 3,93 & 15,13 & 19,65 & 4,52 \\
\hline P17 & 3,76 & 3,93 & 14,78 & 19,65 & 4,87 \\
\hline P18 & 3,78 & 3,94 & 14,89 & 19,70 & 4,81 \\
\hline P19 & 4,04 & 4,18 & 16,89 & 20,90 & 4,01 \\
\hline
\end{tabular}

Tabel 3. Prioritas perbaikan menurut indeks PGCV

\begin{tabular}{|c|c|c|c|}
\hline Prioritas & Atribut & PGCV & Pernyataan \\
\hline 1 & $\mathrm{P} 2$ & 6,04 & $\begin{array}{l}\text { Suasana ruangan yang tenang dan } \\
\text { representative }\end{array}$ \\
\hline 2 & P4 & 5,99 & $\begin{array}{l}\text { Fasilitas pendukung sangat } \\
\text { lengkap }\end{array}$ \\
\hline 3 & P6 & 5,95 & $\begin{array}{l}\text { Pelayan memberikan pelayanan } \\
\text { dengan cepat }\end{array}$ \\
\hline 4 & P1 & 5,83 & $\begin{array}{l}\text { Kebersihan dan kerapian ruangan } \\
\text { sangat terjaga }\end{array}$ \\
\hline 5 & P7 & 5,73 & $\begin{array}{l}\text { Pelayan memberikan informasi } \\
\text { yang tepat }\end{array}$ \\
\hline 6 & P3 & 5,66 & Penerangan ruangan sangat cukup \\
\hline 7 & P5 & 5,54 & Area parkir luas dan aman \\
\hline 8 & $\mathrm{P} 10$ & 5,50 & $\begin{array}{l}\text { Segera memberikan pelayanan } \\
\text { yang tepat sesuai dengan } \\
\text { keinginan pelanggan }\end{array}$ \\
\hline 9 & P8 & 5,38 & $\begin{array}{l}\text { Pelayan menyajikan pesanan } \\
\text { sesuai dengan janji yang } \\
\text { disampaikan }\end{array}$ \\
\hline 10 & P11 & 5,30 & $\begin{array}{l}\text { Kecepatan pelayan dalam } \\
\text { merespon keluhan pelanggan }\end{array}$ \\
\hline 11 & $\mathrm{P} 13$ & 5,13 & $\begin{array}{l}\text { Jam Buka Pit Stop Kopi tepat } \\
\text { waktu }\end{array}$ \\
\hline 12 & P17 & 4,87 & $\begin{array}{l}\text { Petugas sabar dalam melayani } \\
\text { pelanggan dan mendengarkan } \\
\text { keinginan pelanggan }\end{array}$ \\
\hline 13 & P18 & 4,81 & $\begin{array}{l}\text { Petugas bersikap ramah dan } \\
\text { sopan }\end{array}$ \\
\hline 14 & $\mathrm{P} 12$ & 4,75 & $\begin{array}{l}\text { Pelayan memberikan penjelasan } \\
\text { tentang produk yang dijual dengan } \\
\text { lengkap }\end{array}$ \\
\hline 15 & $\mathrm{P} 15$ & 4,72 & $\begin{array}{l}\text { Pelayanan kepada pelanggan } \\
\text { harus dilakukan dengan tepat. }\end{array}$ \\
\hline 16 & P9 & 4,64 & $\begin{array}{l}\text { Pemberian informasi yang cukup } \\
\text { jelas kepada pelanggan }\end{array}$ \\
\hline 17 & P16 & 4,52 & $\begin{array}{l}\text { Pelayanan yang baik tanpa } \\
\text { memandang status social }\end{array}$ \\
\hline 18 & $\mathrm{P} 14$ & 4,49 & $\begin{array}{l}\text { Pelayanan kepada pelanggan } \\
\text { harus dilakukan dengan cepat. }\end{array}$ \\
\hline 19 & P19 & 4,01 & $\begin{array}{l}\text { Pelayan selalu memberikan sikap } \\
\text { senyum sapa dan santun }\end{array}$ \\
\hline
\end{tabular}

Dari tabel 2 diketahui nilai PGCV untuk masing-masing atribut. Selanjutnya yaitu melakukan rangking dari nilai PGCV tertinggi sampai terendah untuk selanjutnya dilakukan perbaikan sesuai dengan layanan prioritas pertama sampai dengan yang terakhir. Atribut dengan nilai PGCV tertinggi akan menjadi prioritas utama dalam perbaikan kualitas pelayanan untuk meningkatkan kepuasan pelanggan. Nilai PGCV tertinggi adalah P2 yaitu pada atribut Suasana ruangan yang tenang dan representatif dengan nilai indeks PGCV sebesar 6,04 (Tabel 3)..

Jika dibandingkan hasil dari indeks PGCV, yang menjadi skala prioritas pertama adalah atribut $P 2$ yaitu suasana ruangan yang tenang dan representatif. Sedangkan hasil analisis dengan importance performance atribut yang masuk dalam kuadran $\mathrm{A}$ harus menjadi prioritas perbaikan. Berikut ini adalah beberapa langkah perbaikan yang dilakukan untuk meningkatkan kualitas pelayanan sehingga memperoleh kepuasan pelanggan.

1. Menurut responden yang juga menjadi pelanggan Pit-Stop Kopi, fasilitas pendukung yang dimiliki oleh Pit-Stop Kopi memang sangat lengkap. Akan tetapi kondisi kebersihan dan perawatan yang dilakukan oleh pihak manajemen kurang maksimal. Ini dibuktikan dengan adanya beberapa sampah yang ditemukan dalam toilet berupa tissue dan plastik yang menyebabkan penilaian responden dalam perhitungan indeks PGCV mempunyai nilai 5,99 yang masuk dalam kategori sangat tinggi untuk segera diperbaiki. Maka dari itu langkah perbaikan yang harus dilakukan yaitu dengan melakukan pembersihan secara rutin terhadap fasilitas penunjang yang dimiliki oleh Pit-Stop Kopi.

2. Menurut responden yang juga menjadi pelanggan Pit-Stop Kopi, area parkir yang dimiliki oleh Pit-Stop Kopi cukup luas dan aman. Akan tetapi penataan parkir kendaraan belum rapi. Hal ini dapat menyebabkan keluar masuknya kendaraan saat parkir sangat sulit karena terhalang beberapa kendaraan yang terparkir dengan posisi sembarangan. Penataan parkir yang baik oleh petugas parkir harus selalu diperhatikan sehingga efektivitas penggunaan lahan parkir bisa maksimal.

3. Menurut responden yang juga menjadi pelanggan Pit-Stop Kopi, pelayanan yang diberikan oleh pelayan memang sangat tepat dan sesuai dengan keinginan pelanggan. Akan tetapi dari segi waktu tunggu, pelanggan 
sering merasa bahwa pelayan sering lambat untuk menghidangkan pesanan kepada pelanggan. Hal ini yang sering dikeluhkan oleh pelanggan. Oleh karena itu pelayan harus memperhatikan ketepatan dan kecepatan dalam melayani pelanggan sehingga akan tercipta rasa puas oleh pelanggan.

\section{KESIMPULAN}

Berdasarkan hasil analisis dan pembahasan yang dilakukan diketahui nilai ratarata gap adalah sebesar $-0,28$ dengan prioritas perbaikan fasilitas pendukung sangat lengkap, area parkir luas dan aman dan memberikan pelayanan yang tepat sesuai dengan keinginan pelanggan. Tindakan perbaikan yang dilakukan untuk meningkatkan kualitas pelayanan yaitu melakukan pembersihan secara rutin terhadap fasilitas penunjang yang dimiliki oleh Pit-Stop Kopi, Penataan parkir yang baik oleh petugas parkir harus selalu diperhatikan sehingga efektivitas penggunaan lahan parkir bisa maksimal, pelayan harus memperhatikan ketepatan dan kecepatan dalam melayani pelanggan sehingga akan tercipta rasa puas oleh pelanggan.

\section{DAFTAR PUSTAKA}

Darmawan, A., Mulyadi, M., \& Busri, N. K. (2014). Analisis Kepuasan Pelanggan Terhadap Layanan Purna Jual Avanza Dengan Metode Servqual Dan PGCV (Studi Kasus BPPT Hadji Kalla Cabang Urip Makassar). Jemis.Ub.Ac.ld, 2(2), 12-19.

Devani, V., \& Rizko, R. A. (2016). Metode Customer Satisfaction Index ( CSI ) Dan Potential Gain in Customer Value ( PGCV ). Jurnal Rekayasa Dan Manajemen Sistem Informasi, 2(2), 24-29.

Erni, N., Sriwana, I. K., \& Yolanda, W. T. (2014). Peningkatan Kualitas Pelayanan dengan Metode Servqual dan TRIZ. Jurnal IImiah Teknik Industri, 2(2), 92-100.

Jalal, R. A., \& Jayamandau, I. (2016). Analisis Tingkat Kualitas Pelayanan Dengan Mengintegrasikan Metode Service Quality $\mathrm{Ke}$ Dalam Metode Importance And Performance Analysis (Studi Kasus: Cha Cha Milk Tea). Teknoin, 22(1), 637-647.

Nuryani, A. R. P., Santoso, I., \& Deoranto, P. (2014). Analisis Kualitas Pelayanan Terhadap Kepuasan Konsumen Dengan Metode Servqual ( Studi Kasus di Ria Djenaka Coffee House \& Resto, Malang ). Ftp Unbraw, (Quadrant I), 1-8.

Ranitaswari, P. A., Mulyani, S., \& Sadyasma, C.
A. B. (2018). Analisis Kepuasan Konsumen Terhadap Kualitas Produk Kopi Dan Kualitas Pelayanan Menggunakan Metode Importance Perfomance Analysis (Studi Kasus Di Geo Coffee). Rekayasa Dan Manajemen Agroindustri, 6(2), 147-157.

Sukwadi, R. (2014). Penentuan Prioritas Perbaikan Kualitas Layanan TransJakarta dengan Menggunakan Metode IPA-PGCV. Jurnal Rekayasa Sistem Industri, 5(2), 6469.

Supranto, J. (2006). Pengukuran Tingkat Kepuasan Pelanggan Untuk Menaikkan Pangsa Pasar. Jakarta: Rineka Cipta.

Suyitno, A., \& Sudarso, I. (2019). Desain Peningkatan Kepuasan Pelanggan Dengan Pendekatan Metode Servqual dan IPA Di Underpass Cafe. Seminar Nasional Inovasi Dan Aplikasi Teknologi Di Industri 2019, 137-141. Malang: SENIATI 2019 - Institut Teknologi Nasional Malang.

Tjiptono, F. (2008). Service Management Mewujudkan Layanan Prima. Yogyakarta: Andi.

Wicaksono, B., Setyanto, N. W., \& Oktavianty, O. (2014). Analisis Kepuasan Pelanggan Pada Pelayanan Kesehatan Dengan Menggunakan Metode Potential Gain in Customer Value (PGCV) Dan Entropy (Studi Kasus: Rumah Sakit Mardi Waluyo Kota Blitar). Jurnal Rekayasa Dan Manajemen Sistem Industri, 2(3), 637-647.

Winarno, H., \& Absror, T. (2017). Analisis Kualitas Pelayanan Dengan Metode Service Quality ( Servqual ) Dan Importance Performance Analysis ( Ipa ). Jurnal Manajemen Industri Dan Logistik, 1(2), 6779.

Widyarto, W. O., Djamal, N., \& Adhim, F. (2018). Analisis Kualitas Pelayanan Publik dengan Metode Fuzzy-Service Quality (F-Servqual) dan Index Potential Gain Customer Value (IPGCV). Jurnal Sistem dan Manajemen Industri, 2(2), 101-110. 